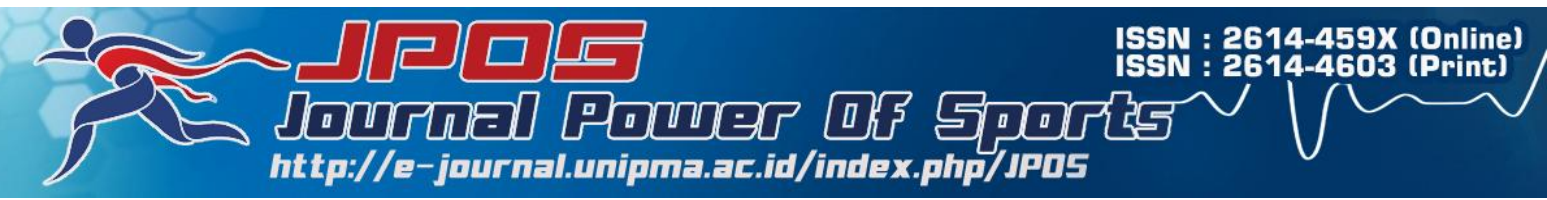

\title{
Analisis pelaksanaan manajemen Pemusatan Pendidikan dan Latihan Olahraga Pelajar (PPLOP) sepak takraw Jawa Tengah tahun 2017
}

\author{
Andhika Yahya Putra ${ }^{1}$, Siswandari ${ }^{2}$, Sapta Kunta Purnama ${ }^{3}$ \\ Program Pascasarjana, Universitas Sebelas Maret, Indonesia \\ Email: andhika.penjas09@gmail.com ${ }^{1}$, namaku_ndari@yahoo.com ${ }^{2}$ \\ saptakunta_p@yahoo.com ${ }^{3}$
}

\begin{abstract}
Abstrak
Penelitian ini bertujuan untuk: (1) Mengetahui struktur organisasi PPLOP sepak takraw Jawa Tengah (2) Mengetahui proses tahapan yang dilakukan dalam perekrutan atlet di Pemusatan Pendidikan dan Latihan Olahraga Pelajar (PPLOP) sepak takraw Jawa Tengah. (3) Mengetahui manajemen sarana dan prasarana dalam mendukung prestasi atlet PPLOP sepak takraw Jawa Tengah. (4) Mengetahui pelaksanaan manajemen keuangan di PPLOP sepak takraw Jawa Tengah. (5) Mengetahui pelaksanaan manajemen latihan PPLOP sepak takraw Jawa Tengah. Penelitian dilaksanakan di Balai Pemusatan Pendidikan dan Latihan olahraga Pelajar (PPLOP) sepak takraw Jawa Tengah. Penelitian ini menggunakan metode diskriptif kualitatif. Unit anlisisnya adalah Balai Pemusatan Pendidikan dan Latihan Olahraga Pelajar (PPLOP). Tehnik pengambilan data melalui studi dokumentasi, wawancara secara mendalam, dan observasi. Sumber data dalam penelitian ini adalah pengurus, pelatih dan atlet PPLOP sepak takraw Jawa Tengah. Hasil penelitian menunjukkan bahwa: pelaksanaan manajemen Pusat Pembinaan dan Latihan Olahraga Pelajar (PPLOP) sepak takraw Jawa Tengah pada umumnya sudah baik. (1) Struktur Organisasi PPLOP sepak takraw sudah sudah baik yang mana sudah memiliki unsurunsur organisasi yang terus berupaya memfasilitasi atlet untuk berprestasi. (2) Proses perekrutan atlet sudah dilaksanakan dengan baik karena sangat selektif dan sudah sesuai dengan kriteria/bencmark yang ditentukan Kemenpora (3) Pelaksanaan manajemen sarana dan prasarana kurang baik, hal ini dikarenakan media pendukung fasilitas atlet PPLP belum lengkap sepenuhnya dan hanya memanfaatkan apa yang ada saja. (4) Pelaksanaan manajemen keuangan telah dilaksanakan dengan baik karena sudah sesuai dengan porsinya masing-masing. (5) Pelaksanaan manajemen latihan di Pusat Pembinaan dan Latihan olahraga Pelajar ( PPLOP) sudah perjalan dengan baik. Mengingat alokasi dana dari APBN dan ABPD yang terbatas, sehingga pengelolaan hanya memaksimalkan dana yang ada.
\end{abstract}

Kata kunci: Pelaksanaan manajemen PPLOP; struktur organisasi PPLOP; perekrutan atlet; manajemen sarana dan prasarana; manajemen keuangan; manajemen latihan. 

sport (PPLOP) sepak takraw Central Java Year 2017

\begin{abstract}
This study objective is to know: (1) Organization structure PPLOP Central Java sepak takraw (2) The stage process in athlete recruitment at Centralization Education and Training Student Sport (PPLOP) Sepak Takraw Central Java. (3) Facility and infrastructure management in supporting PPLOP sepak takraw athlete achievements Central Java. (4) Implementation of management financial at PPLOP Sepak Takraw Central Java. (5) Implementation of Training Management PPLOP sepak takraw Central Java. This study is conducted in Association of Centralization Education and Training Student Sport (PPLOP) Sepak Takraw Central Java. This study is using descriptive qualitative method. The technique of data collection is documentation, in-depth interviewing, and observation. The data source is manager, coach, and PPLOP sepak takraw central java athlete. The result: the management implementation of Centralization Education and Training Student Sport (PPLOP) Sepak Takraw Central Java has been good overall. (1) Organization Structure of PPLOP Sepak Takraw has been good, in which already has elements of the organization that keep trying to facilitate athletes to achieve. (2) The athlete recruitment has been held well because of very selective and appropriate to the Kemenpora benchmark criteria. (3) The implementation of facility and infrastructure management is not good, because supporting media for PPLOP athlete facility is not completed and taken advantage of the stuff around. (4) The implementation of financial management has been good, because the division is evenly distributed. (5) The implementation of training management in Centralization Education and Training Student Sport (PPLOP) has been already well.
\end{abstract}

Keywords: The implementation of PPLOP management; organization structure of PPLOP; athlete recruitment; facility and infrastructure management, financial management; training management.

How To Cite : Yahya P, A., Siswandari., Purnama K, S. (2018). Analisis pelaksanaan to APA Style manajemen Pemusatan Pendidikan dan Latihan Olahraga Pelajar (PPLOP) sepak takraw Jawa Tengah Tahun 2017. JPOS (Journal Power Of Sports), 1 (1), 29-39.

\section{PENDAHULUAN}

Olahraga merupakan salah satu wujud dari upaya peningkatan kualitas manusia yang bertujuan untuk pembentukan watak dan kepribadian, disiplin dan sportifitas yang tinggi, serta peningkatan prestasi yang dapat membangkitkan rasa kebanggaan nasional. Dilain sisi prestasi dalam bidang olahraga merupakan salah satu tolok ukur suatu kemajuan bangsa yang mempunyai peran sangat penting bagi upaya pembentukan dan peningkatan kualitas sumber daya manusia untuk pembangunan.
Proses pembinaan dan pengembangan prestasi olahraga tersebut tentunya membutuhkan atlet-atlet yang memiliki potensi yang tinggi. Untuk mendapatkan atlet berpotensi maka perlu adanya pembinaan dan pengembangan prestasi pada usia produktif yakni tingkat usia sekolah. Berdasarkan arah tersebut di atas maka pemerintah mendirikan model pembinaan di kalangan pelajar yang disebut dengan Diklat pelajar di beberapa propinsi di Indonesia dengan objek sasaran pelajar terutama siswa yang disebut dengan Pusat Pendidikan dan Latihan Olahraga Pelajar (PPLP), yang sekarang 
diubah menjadi balai Pemusatan Pendidikan dan Latihan Olahraga Pelajar (PPLOP) Pelajar adalah sumber daya manusia yang paling tepat untuk menjadi sasaran mencari cikal bakal munculnya atlet berprestasi di masa yang akan datang.

Dalam perjalanan usianya yang sudah relatif lama, PPLP yang sekarang berganti nama menjadi PPLOP telah berhasil menyumbangkan sejumlah atlet junior Nasional dibeberapa cabang olahraga untuk mewakili Indonesia di arena regional maupun internasional. Salah satu cabang olahraga yang menyumbangkan atlet junior adalah Sepak takraw.

Kejuaraan yang diikuti oleh atlet PPLOP antara lain yaitu Popnas (Pekan Olahraga Pelajar Nasional) yang diadakan dua tahun sekali pada tahun ganjil, Popwil (Pekan Olahraga Wilayah) yang diadakan dua tahun sekali pada tahun genap, Kejurnas (Kejuaraan Nasional) yang diadakan satu tahun sekali. Disanalah tempat bertanding kompetisi tingkat nasional para atlet PPLOP untuk menunjukkan keunggulan masing-masing wilayah dan juga membuktikan sejauh mana latihan yang dilakukan setiap harinya membuahkan hasil ataukah tidak. Kenyataan di lapangan dalam Popnas, Popwil, dan Kejurnas cabang sepak takraw dari tahun 2007 sampai dengan sekarang (2017) PPLOP sepak takraw Jawa Tengah adalah PPLOP yang selalu keluar menjadi juaranya. Disisi lain sarana dan prasarana atlet tergolong kurang memadai. Asrama dan tempat latihan yang ala kadarnya dan cenderung tidak memenuhi standart. Dengan kesenjangan tersebut tentunya PPLOP sepak takraw Jawa Tengah perlu diamati. Pasti ada faktor pelaksanaan manajemen tertentu yang menyebabkan PPLOP sepak takraw Jawa Tengah selalu keluar menjadi juara umum sejak tahun 2007 sampai sekarang. Dengan kata lain PPLOP yang minim perhatian tentang sarana dan prasarana atlet tetapi tetap bisa berprestasi.
Dengan berdasarkan pada latar belakang yang dikemukanan sebelumnya, maka rumusan masalah yang akan dikemukakan adalah: Bagaimana struktur organisasi PPLOP sepak takraw Jawa Tengah? Bagaimanakah proses tahapan yang dilakukan dalam perekrutan atlet di PPLOP sepak takraw Jawa Tengah? Apakah sarana dan prasarana yang dibutuhkan telah sesuai dengan kebutuhan atlet pelajar? Bagaimanakah pelaksanaan manajemen pendanaan di PPLOP sepak takraw Jawa Tengah? Bagaimana pelaksanaan manajemen latihan PPLOP sepak takraw Jawa Tengah.

\section{METODE PENELITIAN}

Jenis penelitian yang digunakan adalah penelitian kualitatif dan bersifat deskriptif. Alasan yang mendasarinya adalah karena dalam penelitian ini mengambil masalah keadaan penerapan manajemen PPLOP sepak takraw Jawa Tengah, yang disajikan secara deskriptif, bukan merupakan pernyataan jumlah dan tidak dalam bentuk angka-angka

Penelitian ini akan dilakukan di Balai Pemusatan Pendidikan dan Latihan Olahraga Pelajar Provinsi Jawa Tengah. Teknik pengambilan sampel yang digunakan adalah purposive sampling dan snowball sampling. Sumber data dalam penelitian ini meliputi para pengelola, pelatih dan atlet PPLOP sepak takraw jawa tengah. Teknik Pengumpulan data dilakukan dengan cara mengkaji data dan arsip (content analysis), wawancara mendalam (in-depth interviewing), observasi (observation). Selanjutnya dilakukan reduksi data untuk pemfokusan, penyederhanaan dan kemudian dilakukan deskripsi dalam bentuk narasi yang memungkinkan simpulan penelitian dapat dilakukan. Sedangkan, untuk menetapkan keabsahan data digunakan teknik pemeriksaan dengan empat kriteria yaitu derajat kepercayaan (credibility), keteralihan (transferability), kebergantungan (dependability), dan kepastian (confirmability). Data yang 
dianalisis secara kualitatif berasal dari data yang diperoleh dari berbagai sumber yaitu wawancara. Tahap analisis data yang dilakukan dalam penelitian ini sebagaimana yang dilakukan yaitu: (1) Pengumpulan Data, (2) Penyajian Data, (3) Reduksi Data, (4) Penarikan Kesimpulan/ Verifikasi.

\section{HASIL DAN PEMBAHASAN}

Berdasarkan pada seluruh rangkaian penelitian dan pengambilan data dari berbagai sumber yang ditemui oleh peneliti maka didapatkan beberapa data yang kemudian menjadi pendukung ketercapaian temuan-temuan penting dalam penelitian ini. Data-data ini diharapkan dapat menjawab rumusan masalah atau juga dapat memberikan banyak informasi yang dapat berguna bagi siapa saja yang membutuhkan. Berikut hasil data yang didapat dari berbagai sumber informasi:

\section{Struktur Organisasi PPLOP Sepak Takraw Jawa Tengah.}

Cabang olahraga sepak takraw pelajar di Indonesia berada dalam naungan organisasi PPLOP (Pemusatan Pendidikan dan Latihan Olahraga Pelajar). Koordinasi dalam organisasi PPLOP sangat diperlukan untuk mendapatkan dukungan yang optimal dari berbagai pihak terkait sebagai pengguna atlet berprestasi. Untuk menyelenggarakan suatu pengelolaan pembinaan idealnya mempunyai struktur organisasi seperti struktur organisasi pada pengelolaan pembinaan pusat (Deputi Binpres \& Iptek Olahraga Kemenegpora: 2006) yaitu terdapat (1) Pembina, (2) penanggung jawab, (3) Ketua Pelaksana, (4) Ketatausahaan, (5) Pelaksana Harian, (6) Pelajar. Secara keorganisasian PPLOP sepak takraw sudah baik dengan semua unsur-unsur organisasinya yang memiliki tugas masing-masing menurut jabatannya.
2. Proses Tahapan yang Dilakukan dalam Perekrutan Atlet PPLOP Sepak Takraw Jawa Tengah.

Gambaran tentang pelaksanaan proses tahapan yang dilakukan dalam perekrutan atlet pelajar di Pemusatan Pendidikan dan Latihan Olahraga Pelajar (PPLOP) Sepak Takraw Jawa Tengah menunjukkan bahwa proses tahapan yang dilakukan dalam perekrutan atlet sudah berjalan dengan baik, terlihat dari promosi yang berjalan dengan baik, hal ini terlihat dari peserta yang mendaftar terdiri dari banyak kabupaten/kota. Karena sosialisasi yang baik dari pengelola PPLOP dalam hal ini Dinas Pemuda dan Olahraga ke sekolah-sekolah yang ada di Kabupaten/Kota di Jawa Tengah.

Proses yang dilaksanakan sudah sesuai prosedur yang telah ditentukan sebelumnya dengan mengikuti aturan aturan yang ada, atlet mengikuti tahap demi tahap proses pelaksanaan seleksi yaitu 3 hari dan merujuk buku panduan yang dikeluarkan oleh Kemenpora dan Bench mark Kemenpora.

Tes yang dilakukan oleh pengelola Pemusatan Pendidikan dan Latihan Olahraga Pelajar (PPLOP) sepak takraw Jawa Tengah sudah sesuai dengan benchmark yang dikeluarkan oleh Kemenpora walaupun peralatan tergolong masih kurang.

Kendala-kendalanya adalah atlet yang dikirimkan oleh kabupaten/kota $50 \%$ adalah bukan atlet, dan 50\% nya lagi adalah atlet pemula dari club-club cabang olahraga. Dilihat dari simetris tubuh (antropometri), masih banyak kabupaten/kota mengirimkan atletnya dengan tinggi badan masih dibawah rata-rata.

Dalam melaksanakan tes, perlu memperhatikan urutan pelaksanaan pengukuran. Jenis-jenis pengukuran yang dalam pelaksanaannya mengharuskan atlet mengeluarkan 
banyak tenaga, hendaknya dilaksanakan di urutan terakhir, seperti pengukuran kapasitas aerobik, kapasitas aerobik maksimal dan kesegaran jasmani berdasarkan Panduan Penetapan Parameter Tes Pada Pusat Pendidikan dan Pelatihan Pelajar dan Sekolah Khusus Olahragawan. (Deputi Binpres \& Iptek Olahraga Kemenegpora, 2006)

Dalam hal ini Pemusatan Pendidikan dan Latihan Olahraga Pelajar (PPLOP) Sepak Takraw Jawa Tengah pada pelaksanaan rekrutmen atlet pelajarnya sudah baik karena sudah merujuk pada buku panduan penetapan parameter tes yang dikeluarkan oleh Kemenpora Deputi Peningkatan Prestasi dan Iptek Olahraga.

\section{Pelaksanaan Manajemen Sarana dan Prasarana PPLOP Sepak Takraw Jawa Tengah.}

Rencana pengadaan sudah disusun dalam program kerja melalui Pemusatan Pendidikan dan Latihan Olahraga Pelajar (PPLOP) sepak takraw Jawa Tengah. Penentuan barang atau sarana yang akan dibeli dimusyawarahkan dengan seluruh pengelola PPLOP sepak takraw Jawa Tengah.

Seperti iventarisasi/alat latihan, kebutuhan perlengkapan asrama atlet dan fasilitasnya, perlengkapan staf keuangan, tata usaha, kebersihan dan keamanan lingkungan asrama dan lainlain. Pemanfaatan sarana dan prasarana latihan telah optimal seperti alat-alat latihan yang di PPLOP sepak takraw Jawa Tengah. Begitu juga dengan penyimpanan peralatan latihan yang ada disesuaikan dengan tempatnya (setelah latihan alat-alat dikembalikan). Pencatatan dan pelaporan sudah ada seperti buku inventaris peralatan yang dipakai, daftar barang, penerimaan dan penggunaan barang. Laporan dilakukan sejalan dengan laporan semesteran atau 6 bulan sekali.

Gambaran tentang pelaksanaan manajemen sarana dan prasarana PPLOP sepak takraw Jawa Tengah di atas menunjukkan bahwa dinilai dari keterlaksanaan semua kegiatan sudah berjalan baik yang meliputi: perencanaan, pengorganisasian atau penyediaan, pendayagunaan atau pemanfaatan, penyimpanan atau pemeliharaan dan pencatatan data atau pelaporan.

Subagio (1990) mengemukakan bahwa pengelolaan sarana dan prasarana merupakan proses kegiatan perencanaan, pengorganisasian, pengadaan, pemeliharaan, penghapusan dan pengendalian logistik atau sarana dan prasarana.

Pemeliharaan, perawatan sarana dan prasarana olahraga sudah cukup. Ini terlihat dari kebersihan dan keteraturan keadaan asrama Pemusatan Pendidikan dan Latihan Olahraga Pelajar (PPLOP) Sepak takraw Jawa Tengah. Bangunan asrama memakai sistem bertingkat 2 (dua) sehingga halaman atau pekarangan asrama dapat dimanfaatkan untuk atlet latihan dan bermain.

Akan tetapi prasarana Pemusatan Pendidikan dan Latihan Olahraga pelajar (PPLOP) sepak takraw Jawa Tengah terhadap latihan belum sepenuhnya baik, artinya Prasarana latihan yang mendukung hanya $60 \%$ saja dari keseluruhan cabang olahraga yang ada. Peralatan menunjang yang lain belum memadai seperti weight training yang masih minim atau peralatan lain penunjang latihan terutama pemanfaatan alat bantú latihan yang kurang standar.

Padahal untuk pengelolaan prasarana dan sarana di Pemusatan Pendidikan dan Latihan Olahraga Pelajar (PPLOP) dapat diartikan sebagai berikut: 
a. Prasarana dan sarana yang dipergunakan dalam penyelenggaraan Pemusatan Pendidikan dan Latihan Olahraga Pelajar (PPLOP) wajib memenuhi jenis, jumlah dan standar Nasional.

b. Standarisasi prasarana dan sarana olahraga yang dipergunakan untuk Pemusatan Pendidikan dan Latihan Olahraga Pelajar (PPLOP) harus disesuaikan dengan standar Nasional.

Bagaimana mungkin Pemusatan Pendidikan dan Latihan Olahraga pelajar (PPLOP) sepak takraw Jawa Tengah dapat mencapai suatu prestasi di tingkat Nasional maupun Internasional, jika prasarana latihannya saja belum mendukung sepenuhnya untuk berlatih. Prasarana latihan adalah sangat penting dan sangat mendukung dalam menunjang atlet berprestasi.

Seperti yang dikatatakan Adhyaksa "disadari bahwa turunnya prestasi olahraga Indonesia memang tidak lepas dari aspek-aspek seperti rendahnya perhatian pemerintah terhadap olahraga Indonesia dan terbatasnya sarana dan prasarana olahraga, minimnya kompetisi yang rutin serta kurangnya penghargaan terhadap atlet-atlet yang berprestasi" Adhyaksa Dault, Hal Aktual Keolahragaan Indonesia, (Majalah Forum Olahraga Diknas, 2004:13)

Sehingga sampai saat ini Pemusatan Pendidikan dan Latihan Olahraga Pelajar (PPLOP) sepak takraw Jawa Tengah hanya memaksimalkan prasarana yang ada saja dalam berprestasi.

\section{Pelaksanaan manajemen keuangan.}

Pelaksanaan manajemen keuangan menunjukkan bahwa APBN melalui dana dekonsentrasi dan APBD sudah terlaksana dengan baik sesuai rencana. Dana dekonsentrasi adalah dana yang dianggarkan oleh Kementrian Pemuda dan Olahraga kepada Dinas Pemuda Olahraga dan Pariwisata (Disporapar) Jawa Tengah untuk pembinaan atlet PPLOP sepak takraw Jawa Tengah yang dikelola oleh Balai Pemusatan Pendidikan dan Latihan Olahraga Pelajar (PPLOP) sepak takraw Jawa Tengah dan bantuan mengikuti kejuaraan antar PPLOP yang dikelola oleh Pengurus Provinsi Bapopsi sepak takraw Jawa Tengah, sedangkan APBD lebih di peruntukkan kepada pembiayaan perawatan asrama PPLOP sepak takraw Jawa Tengah.

Untuk Dana APBD Pemusatan Pendidikan dan Latihan Olahraga Pelajar (PPLOP) sepak takraw Jawa Tengah diperuntukkan biaya operasional asrama.

Untuk Dana Dekonsentrasi terbagi atas 2 jenis yaitu:

a. Pembinaan PPLOP Sepak takraw Jawa Tengah

1) Belanja Barang Non

Operasional Lainnya:

a) Perlengkapan Latihan

b) Pengadaan Sepatu Sekolah

c) Pengadaan Seragam Sekolah

d) Kesehatan

2) Belanja Bahan
a) Pengadaan ATK
b) Dokumentasi dan Laporan
c) Perlengkapan Komputer
d) Konsumsi Atlet

3) Belanja Jasa Lainnya

a) Jasa pelatih dan massage

b) Jasa pengurus asrama

c) Jasa jasa pengurus keamanan

d) Jasa pengelola PPLOP

e) Jasa rapat stakeholder

f) Jasa atlet

4) Belanja Perjalanan Lainnya Dalam Negeri
a) Transport panggil/pulang
b) Transport lokal pelatih
c) Tarnsport try out

5) Kejuaraan antar PPLOP

a) Uang saku atlet

b) Uang saku pelatih dan official 

c) Dokumentasi dan pelaporan
d) ATK
e) Biaya transportasi kejuaraan

b. Belanja Daerah

1) Biaya jasa kebersihan

2) Biaya rekening telepon

3) Belanja air

4) Biaya listrik

5) Belanja bahan obat-obatan

6) Belanja bahan pembantu

7) Belanja pakaian sekolah

8) Belanja pakaian olahraga

9) Biaya penjaringan atlet

10) Belanja modal pengadaan konstruksi/rehab gedung.

Kegiatan manajemen keuangan

di Balai Pemusatan Pendidikan dan Latihan Olahraga Pelajar (PPLOP) sepak takraw Jawa Tengah ini dapat dilaksanakan dengan menggunakan fasilitas yang ada di PPLOP, menggunakan tenaga khusus di bidang keuangan yang menangani penerimaan dan pengeluaran uang untuk keperluan operasional PPLOP sepak takraw Jawa Tengah. Berhubung PPLOP ini milik Pemerintah, semua dana seutuhnya dari pemerintah dan pemerintah daerah.

Gambaran tentang pelaksanaan manajemen keuangan di atas menunjukkan bahwa dinilai dari keterlaksanaan semua kegiatan dan menggalirnya sumber dana dari pemerintah pusat dan pemerintah daerah adalah relatif baik. Tetapi mengingat alokasi dana dekonsentrasi dan APBD terbatas, sehingga pengelola hanya memaksimalkan dana yang ada untuk mengelola PPLOP sepak takraw Jawa Tengah.

Dalam pelaksanaannya, manajemen keuangan Pembinaan PPLOP sepak takraw Jawa Tengah dikelola oleh Balai Pemusatan Pendidikan dan Latihan Olahraga Pelajar (PPLOP) Jawa Tengah bertanggung jawab kepada Kementerian Pemuda dan Olahraga RI melalui Dinas Pemuda Olahraga dan
Pariwisata Provinsi Jawa Tengah dan Pemerintah Daerah.

Mekanisme

Manajemen

Keuangan Pembinaan PPLOP sepak takraw Jawa Tengah diberikan melalui bantuan langsung dimana disporapar menunjuk langsung kepada Balai Pemusatan Pendidikan dan Latihan Olahraga Pelajar (PPLOP) sepak takraw Jawa Tengah, bahwa unit pengelola harus dalam menerima bantuan melengkapi persyaratan sebegai berikut:
a. SK Pembentukan Balai PPLOP.
b. Akta Notaris.
c. Proposal Pembinaan Kegiatan PPLOP.

Setelah berkas dilengkapi dilakukan pembuatan surat perjanjian kerja sama untuk dapat mencairkan dana.

Mekanisme pencairan dana bantuan, tahap awal pembuatan usulan propasal dan disetujui oleh satker/kuasa penggunaan anggaran kemudian penerbitan Surat Perjanjian Kerjasama (SPK). Penerbitan kuitansi sesuai dengan permintaan yang tertera pada surat perjanjian kerjasama (SPK), kemudian Balai Pelatihan Pemuda dan Olahraga menyerahkan pertanggung jawaban kepada bendahara penerimaan pengeluaran.

Kemudian berkas pertangung jawaban diserahkan kepada KPKN Ketua Balai Pemusatan Pendidikan dan Latihan Olahraga Pelajar (PPLOP) sepak takraw Jawa Tengah, sebagai manajer, berfungsi sebagai otorisator, dan dilimpahi fungsi ordonator untuk memerintahkan pembayaran untuk proses pembinaan PPLOP Sepak takraw Jawa Tengah. Namun tidak dibenarkan melaksanakan fungsi bendaharawan, juga dilimpahi fungsi donatur untuk menguji hak atas pembayaran proses pembinaan PPLOP Sepak Takraw Jawa Tengah. 
Pada PPLOP sepak takraw

Jawa Tengah Kepala Balai Pemusatan Pendidikan dan Latihan Olahraga Pelajar (PPLOP) adalah sebagai manajer berfungsi sebagai otorisator, ordonatur, tetapi hanya sebatas pengelolaan uang ekstrakurikuler saja. Dengan demikian Kepala Balai Pemusatan Pendidikan dan Latihan Olahraga Pelajar (PPLOP) sepak takraw Jawa Tengah dalam menjalankan tugasnya hanya dari pemanfaatan dana, partisipasi pelatih dalam manajemen keuangan yang telah dilaksanakan dengan baik. Dengan terkelolanya manajemen keuangan yang meliputi: Penyusunan rancangan anggaran pembiayaan belanja PPLOP sepak takraw Jawa Tengah, pengadaan dan sumber dana, pemanfaatan dana, pertanggungjawaban dan pengerjaan data-data keuangan PPLOP sepak takraw Jawa Tengah, sehingga manajemen keuangan Balai Pemusatan Pendidikan dan Latihan Olahraga Pelajar (PPLOP) sepak takraw Jawa Tengah dimasa yang akan datang dapat berjalan lancar, tertib, dan teratur, serta mencapai tujuan pembinaan PPLOP sepak takraw Jawa Tengah, karena manajemen keuangan merupakan salah satu sumber daya secara langsung yang menunjang tercapainya tujuan proses pembinaan PPLOP sepak takraw Jawa Tengah dan merupakan potensi yang sangat menentukan terlaksananya kegiatan pembinaan PPLOP sepak takraw Jawa Tengah, disamping dengan komponen lainnya.

5. Perencanaan Program Latihan di Pemusatan Pendidikan dan Latihan Olahraga Pelajar (PPLOP) Sepak Takraw Jawa Tengah sesuai dengan yang diharapkan Kemenpora.

Pelaksanaan perencanaan program di Pemusatan Pendidikan dan Latihan Olahraga Pelajar sepak takraw Jawa Tengah sudah berjalan dengan baik, secara bertahap sudah menunjukkan tercapainya sasaran sesuai yang diharapkan Kemenpora. Yaitu Pendirian Pemusatan Pendidikan dan Latihan Olahraga pelajar (PPLOP) sebagai salah satu alternatif untuk melakukan pembinaan dan pengembangan olahragawan pelajar potensial berbakat dan minat yang tinggi dibidang olahraga untuk dikembangkan guna mencapai prestasi optimal, baik sebagai olahragawan regional mewakili daerah maupun menjadi salah satu tumpuan pasukan olahragawan nasional untuk mewakili bangsa dan negara dalam event olahraga internasional (Deputi Bidang Peningkatan Prestasi dan Iptek Olahraga: 4) Pemusatan Pendidikan dan Latihan Olahraga Pelajar (PPLOP) juga memiliki tujuan menghasilkan Olahraga pelajar nasional berprestasi di bidang olahraga dan akademik.

Salah satu perencanaan program latihan adalah mengadakan try out yang merujuk pada buku pedoman yang dikeluarkan oleh Deputi Bidang Peningkatan Prestasi dan Iptek Olahraga Kementrian Pemuda dan Olahraga bahwa Latihan, Kompetisi, Akademik dan kesejahteraan sudah diatur yaitu kompetisi:

a) Kompetisi cabang olahraga antar PPLOP dilaksanakan secara periodik.

b) Setiap kegiatan kompetisi nasional cabang olahraga antar PPLOP wajib diikuti oleh semua PPLOP.

c) Pemerintah Daerah yang ditetapkan sebagai penyelenggara bertanggung jawab terhadap pelaksanaan kompetisi antar PPLOP dengan melibatkan induk organisasi dan masyarakat.

$\begin{array}{lrr}\text { Walapun terkadang } & \text { juga } \\ \text { terdapat kendala yaitu } & \text { tidak } \\ \text { melaksanakan tryout } & \text { karena } \\ \text { minimmnya } & \text { kompetisi } & \text { dan } \\ \text { keterbatasan anggaran. Terkadang juga }\end{array}$


jadwal

pertandingan/kejuaraan

dilakukan dengan programnya PPLOP tidak sesuai, ketika masih program masih dalam persiapan umum, tiba-tiba muncul jadwal pertandingan yang sudah didepan mata. Terkadang jadwal mundur, atlet-atlet PPLOP bukanlah TNI/Polri yang siap kapan saja.

\section{KESIMPULAN}

Kesimpulan yang dimunculkan dalam penelitian ini merupakan temuantemuan penting yang peneliti temukan berdasarkan data dan analisis juga pembahasan yang sebaik-baiknya, dan temuan-temuan tersebut berupa:

1. Organisasi PPLOP sepak takraw sudah baik yang mana sudah memiliki unsurunsur organisasi, seperti: kepengurusan dan manajemen organisasi, anggaran dasar rumah tangga, anggaran dana, dan rencana kerja. Dari semua unsur sudah dilaksanakan dengan baik, sedangkan manajemen PPLOP sepak takraw juga sudah cukup baik, dimana terus berupaya memfasilitasi atlet untuk berprestasi.

2. Pelaksanaan proses tahapan yang dilakukan dalam perekrutan atlet di Pemusatan Pendidikan dan Latihan Olahraga Pelajar (PPLOP) sepak takraw Jawa Tengah sudah berjalan dengan baik, dengan adanya pantauan atlet berprestasi dalam tiap kejuaran Popda tingkat kota/kabupaten dan provinsi serta informasi ke seluruh Dispora kota/kabupaten, terbukti dengan hasil prestasi yang diperoleh oleh atlit PPLOP sepak takraw Jawa tengah dari tahun ketahun meningkat dengan predikat juara umum.

3. Sarana dan prasarana yang ada sebenarnya masih kurang memadai di tinjau dari standar yang di tetapkan okeh Kemenpora. Tempat tinggal atlet/ asrama yang apa adanya dan cenderung kurang layak untuk dipakai, sehingga dalam pelaksanaanya mereka hanya memanfaatkan yang ada untuk berprestasi.
4. Pelaksanaan manajemen keuangan sudah berjalan sebagaimana mestinya, dilihat pengelolan dana dan pelaporan keuangan dengan melihat kebutuhan yang ada walau masih adanya kendala keuangan tapi masih bisa diatasi oleh pengelola.

5. Perencanaan program latihan di Pemusatan Pendidikan dan Latihan Olahraga Pelajar (PPLOP) sepak takraw Jawa Tengah sesuai dengan yang diharapkan Kemenpora, Berdasarkan temuan diatas, dapat digambarkan pelaksanaan perencanaan program di Pemusatan Pendidikan dan Latihan Olahraga Pelajar sepak takraw Jawa Tengah sudah berjalan dengan baik, sudah menunjukkan tercapainya sasaran sesuai yang diharapkan Kemenpora. Yaitu Pendirian Pemusatan Pendidikan dan Latihan Olahraga pelajar (PPLOP) sebagai salah satu alternatif untuk melakukan pembinaan dan pengembangan olahragawan pelajar potensial berbakat dan minat yang tinggi dibidang olahraga untuk dikembangkan guna mencapai prestasi optimal, baik sebagai olahragawan regional mewakili daerah maupun menjadi salah satu tumpuan pasukan olahragawan nasional untuk mewakili bangsa dan negara dalam even olahraga internasional.

\section{DAFTAR PUSTAKA}

Alisjahbana. (2008). http://fptijateng.multiply.com/journ al/item/305 Sistem Pembinaan dan Reformasi Bangunan Keolahragaan Nasional

Ambar, T., Sulistiyani R. (2003). Manajemen sumber daya manusia: konsep, teori dan pengembangan dalam konteks organisasi publik. Yogyakarta: Graha Ilmu.

Ambarukmi, D. A. dkk. (2007). Pelatihan pelatih fisik level I. Deputi Bidang Peningkatan Prestasi dan IPTEK Olahraga. Kemenpora. 
Dault, A. (2004). Hal Aktual Keolahragaan Indonesia. Jakarta: Majalah Forum Olahraga Diknas.

Deputi Binpres \& Iptek Olahraga Kemenegpora. (2006). Petunjuk pelaksanaan dan teknis penyelenggaraan PPLP. Jakarta: Kemenegpora.

Direktorat Jenderal Olahraga Departemen Pendidikan Nasional. (2004). Pedoman manajemen organisasi olahraga.

Fatah, N. (2003). Landasan manajemen pendidikan. Bandung: PT Remaja Rosdakarya.

Handoko, T, H. (2001). Manajemen personalia dan sumberdaya manusia. Yogyakarta: BPFE Yogyakarta.

Harsuki. (2003). Perkembangan olahraga terkini, kajian para pakar. Jakarta: PT Raja Grafindo Persada.

Hasibuan, S., Malayu. (2005). Manajemen sumber daya manusia. Edisi Revisi. Jakarta: Bumi Aksara.

Husdarta. (2009). Manajemen pendidikan jasmani. Bandung: Alfabeta.

Junusul, H. (2000). Fisiologi olahraga. Jakarta: Departemen Pendidikan dan Kebudayaan.

Kamiso. (1991). Ilmu kepelatihan dasar. Semarang: FPOK IKIP Semarang.

Kristiyanto, Agus. (2012). Pembangunan olahraga untuk kesejahteraan rakyat dan kejayaan bangsa. Surakarta: Yuma Pustaka.

Lutan, R., Suherman, A. (2000). Perencanaan pembelajaran pejaskes. Jakarta: Depdiknas.
Marihot, M., Dearkina, S. (2005). Pengantar manajemen keuangan. Yogyakarta: Andi.

Moleong., Lexy J. (2000). Metodologi penelitian kualitatif. Bandung: PT. Remaja Rosdakarya.

Mulyasa, E. (2005). Menjadi kepala sekolah profesional. dalam konteks menyukseskan MBS dan KBK, Bandung: Rosda Karya.

Noer, A, H. (1996). Kepelatihan Dasar. Jakarta: Pusat Penerbitan Universitas Terbuka Pendidikan dan Kebudayaan.

Republik Indonesia, Undang-undang No. 16 tahun 2007. (2007). Tentang Penyelengaraan Keolahragaan.

Sajoto. (1995). Peningkatan dan pembinaan kekuatan kondisi fisik dalam olahraga. Semarang: Dahara Prize.

Siagian, P , S. (2007). Manajemen sumber daya manusia, Jakarta: PT. Bumi Aksara.

Subardjah. (2000). Bulu tangkis. Bandung: Depdikbud.

Sudjarwo. (1993). Ilmu kepelatihan dasar. Surakarta: UNS Press.

Suhendro, A. (1999). Dasar-dasar kepelatihan. Cetakan Ketiga. Jakarta: Universitas Terbuka. Departemen P\&K.

Syarifudin, A. (1992). Atletik. Jakarta, Depertemen Penelitian dan Kebudayan Direktorat Jenderal Pendidikan Tinggi Proyek Pembinaan Tenaga Pendidikan. 
JPOS (Journal Power Of Sports), 1 (1) 2018, (29-39)

Available at: http://e-journal.unipma.ac.id/index.php/JPOS

Andhika Yahya Putra ${ }^{1}$, Siswandari ${ }^{2}$, Sapta Kunta Purnama ${ }^{3}$

Tangkudung, J. (2006). Kepelatihan

olahraga "membina prestasi

olahraga”. Jakarta: Cerdas Jaya.

Wahjosumirdjo. (2003). Kepemimpinan

kepala sekolah, tinjauan teoritis

dan permasalahannya. Jakarta: PT

Raja Grapindo Persada. 